\title{
ANALISIS TENTANG HIBAH DAN KORELASINYA DENGAN KEWARISAN DAN PEMBATALAN HIBAH MENURUT PERATURAN PERUNDANG-UNDANGAN DI INDONESIA
}

Oleh : Rachmat Rizqy K,Ph.D.

Mohammad Miftahus Sa'di

\begin{abstract}
This study aims to analyze the relationship between wills and inheritance according to Indonesian laws and regulations, and to analyze the possibility of abolishing wills if the realization of wills is more than one-third (1/3). The research method used is normative juridical research with a statute approach. The results of this study are: 1 . The relationship between wills and inheritance according to the Islamic Compilation Law, inheritance from parents to children can be calculated as part of inheritance. According to the Civil Code (KUHPerdata), inheritance is an advance payment (voorschot) as part of the inheritance for the testator.

Keywords : inheritance, grant, Correlation
\end{abstract}

\begin{abstract}
Abstrak
Penelitian ini memiliki tujuan untuk menganalisa hubungan antara wasiat dan pewarisan menurut peraturan perundang-undangan Indonesia, dan menganalisis kemungkinan penghapusan wasiat apabila realisasi wasiat lebih dari sepertiga (1/3). Metode penelitian yang digunakan adalah penelitian yuridis normatif dengan pendekatan statuta. Hasil penelitian ini adalah : 1. Hubungan antara wasiat dan warisan menurut Hukum Kompilasi Islam, warisan dari orang tua kepada anak dapat diperhitungkan sebagai bagian dari harta warisan. Menurut Hukum Perdata (KUHPerdata), warisan adalah pembayaran di muka (voorschot) sebagai bagian dari warisan bagi pewaris.
\end{abstract}

Kata Kunci : Warisan, Hibah, Kolerasi

\section{Pendahuluan}

Menurut Kitab Undang-undang Hukum Perdata (KUHPerd) Pasal 1666 menyatakan bahwa, hibah adalah suatu persetujuan dengan mana si penghibah diwaktu hidupnya dengan suka rela dan dengan tidak ingin untuk ditarik kembali, menyerahkan sesuatu benda guna keperluan si penerima hibah yang menerima penyerahan itu. 
Penghibahan termasuk perjanjiansatu belah pihak kepada pihak yang lain, dimana hanya satu pihak saja yang mempunyai kewenangan atas perjanjian ini, yaitu si penghibah, sedangkan pihak yang menerima hibah sama sekali tidak mempunyai kewenangan. Sebuah perjanjian akan menghasilkan timbal balik, karena yang lazim adalah bahwa orang yang menyanggupi suatu prestasi karena ia akan menerima suatu kontra-prestasi. ${ }^{1}$

Perkataan "diwaktu-hidupnya" si penghibah, adalah untuk membedakan si penghibah itu dari permberian-pemberian yang dilakukan dalam suatu testament (surat wasiat), yang baru akan berlaku setelah si pemberi wasiat itu meninggal dunia, dan dapat dirubah atau ditarik kembali olehnya. Penjelasan dalam pemamaparan itu dinamakan 'Hibah Wasiat' dan sudah diatur dalam undang undang hukum waris, adapun penghibahan ini adalah sebuah perjanjian. Karena devinisi penghibahan itu adalah sebuah Akad, yang dengan sendirinya tak boleh untuk di Tarik kembali. ${ }^{2}$

Dalam hukum adat, yang dimaksud dengan hibah adalah harta kekayaan seseorang yang dibagi-bagikannya diantara anak-anaknya pada waktu ia masih hidup. Penghibahan itu sering terjadi ketika anak-anak mulai berdiri sendiri atau anak-anak mereka mulai menikah dan membentuk keluarga sendiri. Dan disini haruslah peroses Penghibahan itu dilakukan saat si pemberi hibah itu masih hidup, yang bertujuan agar tak terjadi persengketaan anak anaknya setelah ditinggal wafat nanti. Biasanya penghibahan itu terjadi karna adanya rasa khawatir karna ibu dari anak anaknya bukanlah ibu kandung melainkan ibu tiri ,atau juga karena dikalangan anak-anaknya itu terdapat anak angkat yang mungkin disangkal keanggotaannya sebagai ahli waris. ${ }^{3}$ Selain itu ada juga diantara si pemberi hibah karena sangat sayangnya kepada anak angkat dan kurannya ilmu dalam menerapkan hukum islam, sehingga orang tua seringkali menghibahkan seluruh hartan kepada anak anaknya .

\section{Rumusan Masalah}

Bagaimanakah hubungan hibah dengan kewarisan menurut peraturan perundangundangan Di Indonesia ? Lalu, apakah hibah yang telah diberikan (melebihi 1/3 dari harta kekayaan) dapat dibatalkan?

\section{Tujuan Penelitian}

Untuk mengetahui korelasi antara hibah denngan waris dan pembatalan hibah menurut undang undang

\footnotetext{
${ }^{1}$ R Subekti, Aneka Perjanjian, PT Citra Aditya Bakti, Jakarta, 1995, hal 94-95

${ }^{2}$ Ibid

${ }^{3}$ Tamakiran S dalam Abdul Manan, Aneka Masalah Hukum Perdata Islam Di Indonesia, Prenada Media Group, Jakarta, 2008, had
} 


\section{Pembahasan}

\section{Hibah dan Korelasinya dengan Kewarisan menurut Peraturan Perundang- Undangan di Indonesia}

Menurut Kompilasi Hukum Islam (KHI)

Sebagaimana telah diuraikan bahwa hibah, merupakan pemberian dari seseorang pemberi hibah kepada orang lain sebagai penerima hibah ketika si pemberi hibah (yang punya harta) masih hidup, sedangkan warisan diberikan ketika si pewaris (yang punya harta) telah meninggal dunia. Walau waktu pemberiannya taksama namun kedua duanya memiliki hubungan yang berkesinambungan . terutama hibah itu diberikan kepada anak atau ahli waris karena akan menentukan terhadap bagian warisan yang akan diterimanya.

Adapun Pasal 211 menyatakan : hibah yang diberikan oleh orang tua kepada anaknya dapat diperhitungkan sebagai harta warisan.

Betul memang prinsip hibah itu sendiri sudah di jelaskan secara gambling oleh baginda nabi Mohammad SAW. Baiknya bagian mereka disama ratakan.dan jika ingin dibedakan hendaknya semua pihak setuju dan ridho atas pembaian tadi. Oleh karena itu adanya perbedaan pendapat tentang status hukum melebihkan hibah kepada satu anak, tidak kepada orang lain, yang terpenting dalam pemberian hibah tersebut adalah dilakukan secara musyawarah dan atas persetujuan anak-anak yang ada. Ini penting agar tidak terjadi perpecahan dalam keluarga.

Dengan demikian dapat ditegaskan bahwa pemberian hibah dapat diperhitungkan sebagai warisan. Boleh jadi, pola pembagian demikian, oleh sementara pendapat dianggap sebagai sikap mendua kaum muslimin.

Menurut TerHaar penghibahan atau pewarisan (Toescheidingen) merupakan kebalikan dari harta peninggalan yang tidak dapat dibagi-bagi, yaitu pembagian keseluruhan ataupun sebagian dari pada harta-kekayaan semasa pemiliknya masih hidup. ${ }^{4}$

Dasar pokok ataupun motif daripada penghibahan ini adalah tidak berbeda dengan motif daripada tidak memperbolehkan membagi-bagi harta peninggalan kepada para ahli

\footnotetext{
${ }^{4}$ Soerojo Wignjodipuro, Op.cit, hal 171 
waris yang berhak, yaitu harta kekayaan somah merupakan dasar kehidupan materiil yang disediakan bagi warga somah yang bersangkutan beserta keturunannya.

Di samping motif umum ini, khususnya di daerah-daerah yang bersifat kekeluargaan martriarchaat ataupun patriarchaat, penghibahan harta kekayaan demikian ini merupakan juga suatu jalan untuk seorang bapak (di daerah dengan sifat kekeluargaan matriarchaat) ataupun seorang ibu (di daerah dengan sifat kekeluargaan patriarchaat) memberikan sebagian daripada harta-pencahariannya langsung kepada anak-anaknya, hal mana sesungguhnya merupakan penyimpangan daripada ketentuan hukum adat waris yang berlaku di derah-daerah yang bersangkutan (merupakan suatu koreksi ataupun perbaikan terhadap kekakuan ketentuan-ketentuan hukum adat waris yang berlaku). ${ }^{5}$

Hibah orang tua kepada anaknya dapat diperhitungkan sebagai warisan, telah menjadi tradisi atau kebiasaan dikalangan masyarakat Indonesia, dalam sistem kekeluargaan Parental, Matrilineal, dan Patrilineal, dimana pemberian itu dilakukan pada waktu anak menjadi dewasa dan membentuk keluarga yang berdiri sendiri. Kemudian setelah orang tua menghibahkan ini meninggal, dilakukan pembagian harta warisan kepada ahli warisnya, maka hibah tersebut akan diperhatikan serta diperhitungkan dengan bagian yang semestinya diterima oleh anak-anak yang bersangkutan, bila mereka itu belum menerima ini tidak lagi berhak atas harta yang lain yang dibagi-bagi setelah bapaknya meninggal dunia. Akan tetapi, setelah melihat banyaknya harta warisan, ternyata yang telah diterima anak tersebut masih belum cukup, maka ia akan mendapat tambahan pada saat harta peninggalan bapaknya dibagi-bagi. Dengan demikian terlihat hubungan antara hibah dengan warisan, dimana hibah atau pemberian ini dapat diperhitungkan sebagai warisan. Ada sebuah kasus yang berkaitan dengan warisan. Seorang Nenek mempunyai sejumlah harta berupa tanah dan rumah. Sebelum nenek meninggal harta tersebut telah dibagikan kepada anak-anaknya dengan mengutus ayah sebagai anak tertua untuk membagikannya. Pada saat itu telah diterima oleh semua adikadiknya tanpa ada masalah, namun saat itu memang tidak ada surat surat secara hukum. Setelah nenek dan ayah meninggal salah satu adik ayah mengatakan bahwa pembagian itu dulunya ilegal dan tidak adil dan dia menuntut untuk dibagikan kembali. Harap dicatat bahwa bagian yang dia terima dijual dan dibeli oleh saudara perempuannya sendiri dalam hal ini masih bibi saya juga. Sekarang dia memiliki rumah dan tanah yang seharusnya

\footnotetext{
${ }^{5}$ Ibid
} 
menjadi milik saya dan dua paman lainnya. Yang ingin saya tanyakan dalam masalah ini adalah hukum apa yang bisa dijadikan tolak ukur, beliau menganut pasal hukum waris sedangkan dari kronologi saya membaca bahwa itu bukan waris melainkan pemberian.

Sehubungan dengan hal tersebut di atas, Pasal 211 KHI telah memberikan jalan keluarnya, yaitu dengan cara hibah yang diberikan oleh orang tua kepada anaknya dapat dihitung sebagai harta warisan. Makna "dapat" dalam pasal tersebut bukan berarti keharusan (harus), tetapi merupakan salah satu alternatif yang dapat ditempuh untuk menyelesaikan sengketa atau sengketa waris. Selama ahli waris tidak mempersoalkan hibah yang telah diterima oleh sebagian ahli waris, maka harta warisan yang belum dihibahkan dapat dibagikan kepada semua ahli waris sesuai dengan bagiannya masingmasing. Tetapi jika ada ahli waris yang mempersoalkan hibah yang diberikan kepada sebagian ahli waris lainnya, maka hibah tersebut dapat dihitung sebagai harta warisan, dengan memperhitungkan hibah yang telah diterima dengan bagian harta warisan yang seharusnya diterima. Jika hibah yang telah diterima masih kurang dari bagian warisan, maka hanya menambah kekurangan, dan sebaliknya jika hibah melebihi bagian warisan, maka kelebihan hibah dapat ditarik untuk diserahkan kepada ahli waris yang kekurangan. dari porsi.

\section{Menurut Kitab Undang-undang Hukum Perdata (KUHPerd)}

Sebagaimana yang telah diuraikan terdahulu bahwa Inbreng (Pemasukan) adalah memperhitungkan pemberian barang-barang yang dilakukan oleh orang yang meninggalkan harta warisan pada waktu ia masih hidup kepada para ahli waris. ${ }^{11}$ Semua hibah-hibah yang pernah diberi pewaris kepada para ahli waris dalam garis lurus ke bawah (anak cucu dan seterusnya) kecuali kalau pewaris secara tegas membebaskan mereka dari pemasukan, seakan-akan merupakan persekot (uang muka) atas bagian para ahli waris dalam harta peninggalan pewaris. ${ }^{6}$

Inbreng (Pemasukan) diatur dalam Pasal 1086 s.d. 1099 KUHPerdata. Perhitungan itu harus dilakukan ahli waris keturunan dari orang yang meninggalkan harta pada kenyataannya penerima hibah tidak memenuhi kewajibannya untuk memelihara dan merawat pemberi hibah., maka hibah tersebut dapat ditarik kembali oleh pemberi hibah Adapun Islam hanya memberikan kewenangan kepada pemberi 1/3 dari hartanya

\footnotetext{
${ }^{6}$ Soerojo Wongsowidjojo dalam Idris Ramulyo, Ibid 
dan tidak lebih, hibah orang tua kepada anaknya dapat dihitung sebagai ahli waris. Jika hibah dilaksanakan menyimpang dari ketentuan tersebut, diharapkan tidak terjadi perpecahan antar keluarga. Asas-asas yang dianut oleh syariat Islam sesuai dengan budaya bangsa Indonesia dan juga sesuai dengan apa yang dikemukakan oleh Muhammad Ibnul Hasan, bahwa orang yang bertanya semua itu bodoh.

dan tidak layak untuk dilakukan tindakan hukum. Karena orang yang menghibahkan harta itu dianggap tidak cakap untuk bertindak secara hukum, maka hibah yang diberikan dianggap batal, karena ia tidak berhak memberikan sumbangan. ${ }^{7}$

\section{pembatalan Hibah Menurut Hukum Adat}

Pada dasarnya hukum adat mengatur tentang penarikan atau pembatalan hibah yang telah diberikan, apabila hibah tersebut tidak sesuai dengan ketentuan yang berlaku, dalam hal ini ada beberapa daerah yang memperbolehkan penarikan kembali hibah tersebut.

Pada masyarakat adat Jawa Barat, khususnya di Desa Leuwi Liang dan Citeureup, hibah dapat ditarik kembali jika bertentangan dengan ketentuan Hukum Adat dan Hukum Islam. Sebaliknya, di daerah Cianjur, Banjar, Ciamis, dan Cikenong, hibah tidak dapat ditarik kembali meskipun utang ahli waris tidak dapat dilunasi dari harta yang ditinggalkannya. Demikian pula di wilayah Kabupaten Batujaya, Teluk Buyung, Pisang Sambo, Karawang dan Indramayu, jika hibah merupakan hibah mutlak, maka hibah tidak dapat ditarik kembali. ${ }^{8}$

Berdasarkan uraian di atas dapat dikatakan bahwa pembatalan hibah menurut hukum adat ada daerah-daerah tertentu yang tidak dapat ditarik kembali dan ada pula yang dapat ditarik kembali apabila hibah tersebut tidak sesuai dengan ketentuan yang berlaku.

\section{Pembatalan Hibah menurut Kitab Undang-undang Hukum Perdata}

Menurut Kitab Undang-undang Hukum Perdata, tidak ada ketentuan yang memberikan pembatasan tentang hibah yang diberikan si pemberi hibah sebagaimana yang diatur dalam Kompilasi Hukum Islam. Pada prinsipnya hibah yang telah diberikan oleh seseorang kepada orang lain tidak dapat ditarik kembali atau dibatalkan, kecuali dalam hal-hal sebagaimana yang diatur dalam Pasal 1688 KUHPerdata, yaitu : barang itu

\footnotetext{
${ }^{7}$ Wiriono Prodjodikoro dalam Idris Ramulyo,Perbandingan Hukum Kewarisan Islam

${ }^{8}$ Eman Suparman, Op.Cit,hal 93 
hendak atau telah dipindah tangankan, dihipotekkan atau dibebani dengan hak kebendaan lain oleh penerima hibah, kecuali kalau gugatan untuk membatalkan penghibahan itu sudah diajukan kepada dan didaftarkan di Pengadilan dan dimasukkan dalam pengumuman tersebut dalam Pasal 616 KUHPerdata. Semua pemindahtanganan, penghipotekan atau pembebanan lain yang dilakukan oleh penerima hibah sesudah pendaftaran tersebut adalah batal, bila gugatan itu kemudian dimenangkan.

Jika penghibah jatuh miskin sedang yang diberi hibah menolak untuk memberi nafkah kepadanya. Dalam hal ini barang yang telah diserahkan kepada penghibah akan tetapi penerima hibah tidak memberikan nafkah, sheingga hibah yang telah diberikan dapat dicabut atau ditarik kembali karena tidak dilakukannya pemberian nafkah.

\section{Kesimpulan}

Hubungan hibah dengan kewarisan menurut Kompilasi Hukum Islam, dimana hibah yang telah diberikan orang tua kepada anaknya dapat diperhitungkan sebagai warisan. Menurut Hukum Adat hibah telah menjadi tradisi atau kebiasaan dikalangan masyarakat Indonesia dalam sistem kekeluargaan Parental, Matrilineal, dan Patrilineal, dimana orang tua melakukan pemberian (hibah) pada waktu anak menjadi dewasa dan membentuk keluarga. Sedangkan menurut KUHPerdata pemberian yang dilakukan oleh orang yang meningggalkan harta warisan pada waktu masih hidup, dianggap sebagai pemberian didepan ( voorschot) dalam harta warisan dari bagian si ahli waris.

Menurut Kompilasi Hukum Islam, bahwa pada dasarnya hibah tidak dapat dibatalkan atau ditarik kembali, kecuali hibah orang tua kepada anaknya Begitu pula menurut KUHPerdata bahwa hibah yang telah diberikan oleh seseorang kepada orang lain tidak dapat ditarik kembali atau dibatalkan, kecuali: Jika syarat-syarat penghibahan itu tidak dipenuhi oleh penerima hibah, Jika orang yang diberi hibah bersalah dengan melakukan atau ikut melakukan suatu usaha pembunuhan atau suatu kejahatan lain atas diri penghibah, Jika penghibah jatuh miskin sedang yang diberi hibah menolak untuk memberi nafkah kepadanya.

\section{Saran}

Hendaknya Pejabat yang membuat akta hibah memperhatikan rukun dan syarat hibah, agar jangan sampai terjadi pembatalan hibah dikarenakan tidak dipenuhinya rukun dan syarat hibah tersebut. Dan baiknya saat melakukan hibah haruslah para ahli waris menyaksikan peroses serah terima hibah tadi, agar tidak terjadi polemic di kemudian hari. 


\section{DAFTAR PUSTAKA}

Bisri, Cik Hasan, Kompilasi Hukim Islam Dakan Sistem Hukum Nasional, PT Logos Wacana Ilmu, Jakarta, 1999.

Manan, Abdul, Aneka Masalah Hukum Perdata Islam di Indonesia, Prenada Media Group, Jakarta, 2008.

Oemarsalim, Dasar-dasar Hukum Waris Di Indonesia, Rineka Cipta, Jakarta, 2006.

Parangin, Effendi, Hukum Waris, Raja Grafindo Persada, Jakarta, 2010

Pasaribu, Chairuman dan Suhrawardi K. Lubis, Hukum Perjanjian Dalam Islam, Sinar Grafika, Jakarta, 2004.

Ramulyo, Idris, Perbandingan Hukum Kewarisan Islam Dengan Kewarisan Kitab Undang-undang Hukum Perdata, Sinar Grafika, Jakarta, 2004

Rofiq, Ahmad, Hukum Islam Di Indonesia, PT. Raja Grafindo Persada, Jakarta. 2000.

Sabiq, Sayyid, Fiqh Sunnah Edisi ke-14, Al-Ma'arif, Bandung, 1997.

Sidauruk, Gunawan, Hukum Perdata Tentang Perjanjian Bernama, Armico : Bandung, 1981.

Simanjuntak, P.N.H, Pokok-pokok Hukum Perdata Di Indonesia, Djambatan, Jakarta, 2009.

Subekti, Aneka Perjanjian, Citra Aditya Bakti, Bandung, 1995.

Suparman, Eman, Hukum Waris Indonesia Dalam Perspektif Islam,Adat, Dan $B W$, PT Refika Aditama, Bandung, 2011.

Wignjodipoero, Soerojo, Pengantar Dan Asas-asas Hukum Adat, CV Haji Masagung, Jakarta, 1994.

Kitab Undang-undang Hukum Perdata.

Instruksi Presiden No. 1 Tahun 1991 tentang Kompilasi Hukum Islam. 